\title{
Challenges in Implementing STEM Education and Role of Teacher Education Programs in Mitigating these Challenges
}

\author{
Dr. Abdul Nasir Kiazai \\ Assistant Professor \\ IER, University of Balochistan, Quetta \\ mirnasir555@gmail.com \\ Dr. Naila Siddiqua \\ Assistant Professor \\ Department of Education, University of Karachi \\ Dr. Zarina Waheed \\ Assistant Professor \\ Department of Education, SBK, Women University, Quetta
}

\begin{abstract}
STEM instruction is an incorporated methodology that consolidates science, technology, engineering, and mathematics education. This study aimed at finding expected challenges in implementing STEM education and role of teacher education programs in mitigating possible challenges in implementing STEM education in Baluchistan. To achieve the objectives, quantitative methodology was used. Sample was selected using judgmental convenience sampling technique. The sample of the study consisted of, 202 pre-service teacher educators from three public universities of Quetta. The data was analyzed using descriptive statistics including frequencies and percentage. The findings indicated that although the implementation of integrated STEM education in Baluchistan may face challenges, the role of teacher education programs in mitigating these challenges is significant.
\end{abstract}

Keywords: STEM education, Pre-service teachers, Teacher education programs, Baluchistan.

\section{Introduction}

A growing interest can be found among educators regarding implementing integrated science, technology, engineering, and mathematics (STEM) education. Countries like United States, China, Singapore and Turkey are focusing on implementing STEM education (Teo \& Ke, 2014).The reason behind this importance is to make their students ready to cope up with demands of global market where science and technology are being emphasised (Williams, 2011). 
However, countries across the global are facing challenges and problems in implementation of STEM education (Ejiwale, 2013). "Research in integrated STEM can inform

STEM education stakeholders to identify barriers as well as determine best practices" (Kelley \& Knowles, 2016, p. 3). Researchers have highlighted challenges and issues in implementing STEM education and have identified the need to investigate, and tackle issues under STEM education (Hmelo-Silver et al., 2007). On a global level not much has been done on practices of integrated subjects of Mathematics and Science subjects and challenges in implementing STEM education (Asghar et al., 2012).

The role of teacher education institutions in tackling these challenges regarding implementation of STEM education is being recognized (Ryu et al., 2019). Similarly, so far, globally, little has been done to issues for professional development of teachers in integrated subjects of Math and Science subjects, which need to be focused as well (Asghar et al., 2012).According to Awan et al. (2017) in recent years, some growth can be noticed among university level students towards STEM subject mainly due to importance given to STEM Education from school levels.

The purpose of this study was to analyse expected challenges in implementing STEM education and role of teacher education programs in mitigating these possible challenges in Baluchistan. It was considered important to explorethe issue in Pakistan in order to inform education stakeholder regarding the current practices and statusof STEM education. The purpose of the survey study was to analyse possible challenges in implementing STEM education and the role of teacher education programs in mitigating these possible challenges in Baluchistan. 1.1.

\section{Objectives}

The objectives of the study were as follows:

1. To explore possible challenges in implementing STEM Education in Baluchistan.

2. To identify the role of teacher education programs in countering possible challenges in implementing STEM education in Baluchistan.

\subsection{Research Questions}

The research questions of the study are as following:

1. What are the possible challenges in implementing STEM Education in Baluchistan? 
2. What can be the role of teacher education programs in countering possible challenges in implementing STEM education in Baluchistan?

\section{Review of Literature}

STEM Education refers to an interdisciplinary instructive exercise from instructions to evaluation at all levels of education (Gonzalez \& Kuenzi, 2012).According to Cinar et al. (2016), STEM instruction is an incorporated methodology that consolidates science, innovation, designing and mathematics discipline subjects together and at the same time. The focus of STEM is not on remembering the facts related to science, technology, engineering, and mathematics, but is to give students experiences of exploring, inquiring, discovering, innovating, and problem solving in above disciplines (Asghar et al., 2012). STEM education stimulates collaboration, teamwork, creativity, critical thinking and problem solving (Shernoff et al., 2017).

Integrated STEM education is a process of integrating "science, technology, engineering, and mathematics into one class that is based on connections between the subjects and real world problems (Stohlmann et al., 2012, p30)". According to Breiner et al. (2012), it is not necessary that all the four subjects should be included in STEM education, integrating more than one subjects to get required skills and knowledge can fulfil the criteria. The purpose of integrating these interdisciplinary subjects is to give an opportunity to the gifted students to intensify their learning and reasoning skills and motivate them towards learning and getting grades of higher levels (Meyrick, 2011). Due to its advantages, opportunities are also provided to the students from mainstream education. Government policymakers have keen interest in STEM Education and trainings to bring science, instruction, workforce, national security, and migration strategy together.

According to Asghar et al. (2012), science related researchers emphasize the essentialness of an integrative, interdisciplinary STEM training that supports students to find out about the real world through investigation, applying, and problem solving skills. Researchers claim that students ought to participate in discovering that enables them to investigate, ask, tackle issues, and think critically (Hmelo-Silver et al., 2007).STEM instruction incorporates the information, abilities and convictions that are built at the crossing point of more than one STEM subject area (Corlu et al., 2014). 
STEM practices are quite mature in western countries like UK, USA and Australia (Gonzalez,\& Kuenzi, 2012). However, the integrated STEM education is not familiar in many developing countries since it demands extensive training and expertise on the part of teachers and also needs availability of required teaching learning resources. According to Awan et al.(2017)the ratio of students in STEM subjects-Science, Technology, Engineering, and Mathematics- is increasing in Pakistan. According to them, it has reached to 55.7 in Male and 44.2 in female, which was very low in 2010. This occurred because of motivating student for STEM subjects at school by teachers in Pakistan. However, in their study they have considered all STEM subjects as single disciplines rather than integrative STEM.

Moreover, the pre-service teacher educations programs are considered as playing instrumental role in preparing more innovative future teachers capable of effectively implementing integrated STEM education. According to Honey et al. (2014) the preparation of pre-service teachers with appropriate content knowledge for integrated STEM education is given least attention as compared to in-service trainings. According to Teo and Ke (2014), Singapore also does not have any teacher education program for preparing future teachers to teach in STEM schools. Shernoff et al. (2017) found that the current pre-service teacher education programs are deficient as their emphasis is on content knowledge, standards of curriculum and teaching strategies rather than on integrating STEM instruction. Kuenzi (2008) while discussing the legislative developments in STEM education in USA, declared that the USA is giving importance to pre-service teacher education programs for preparing skilled teachers.

Shernoff et al. (2017) suggested that the pre-service teacher education programs should include multidisciplinary courses and approaches for training prospective teachers for designing multiple STEM related activities or experiments. Ryu et al. (2019) interviewed and reviewed the artifacts of pre-service teachers' experiences of STEM integration and barriers for integrated STEM. They found that pre-service teachers are trained in using different strategies to integrate STEM lessons with effective activities and experiments. They were able to integrate STEM related disciplines extraordinarily. Koirala and Bowman (2003) designed a course for pre-service teacher educators to integrate science and mathematics through team-teaching. They found that due to this course the understanding and appreciation of future teachers regarding integration enhanced. They considered this integration as meaningful. The pre-service teacher education programs can train 
future teachers for integrating STEM subjects in terms of discipline, content, process and techniques (Koirala \& Bowman, 2003).

\subsection{Theoretical Framework of the Study}

This study is mainly based on Kelley and Knowles's (2016) conceptual framework of integrated STEM education for secondary education. Their framework is based on various learning theories that can help students in learning. This framework is based on components such as situated learning, engineering design, scientific inquiry, technological literacy, and mathematical thinking and every compnent is based on set of practices of STEM Education. The first compnent in this framework involves situated learning which mainly focuses on application practices of STEM knowledge and skills in the physical and social contexts. The second compnent 'Engineering design' works as catalyst in brining all four subjects of STEM together and helps students in solving the problems that they may encounter in STEM subjects. The third component is 'scientific inquiry', which debates on the importance of instructional strategies that have their own procedures and practices to prepare students with scientific skills of asking questions, problem solving, investigating scientific concepts.

The fourth component 'Technological literacy' is a discipline that involves knowledge, skills, and practices to use design and make technology in STEM Education. It mainly focuses in making students equipped technologically and making them able to understand the cultural, social, political and economic aspects of technology. The last component is 'mathematical thinking practices' which is based on the practices of analysing mathematical problems and connecting them to other STEM disciplines. Figure 1 below shows the theoretical framework of the study. 


\section{STEM Education}

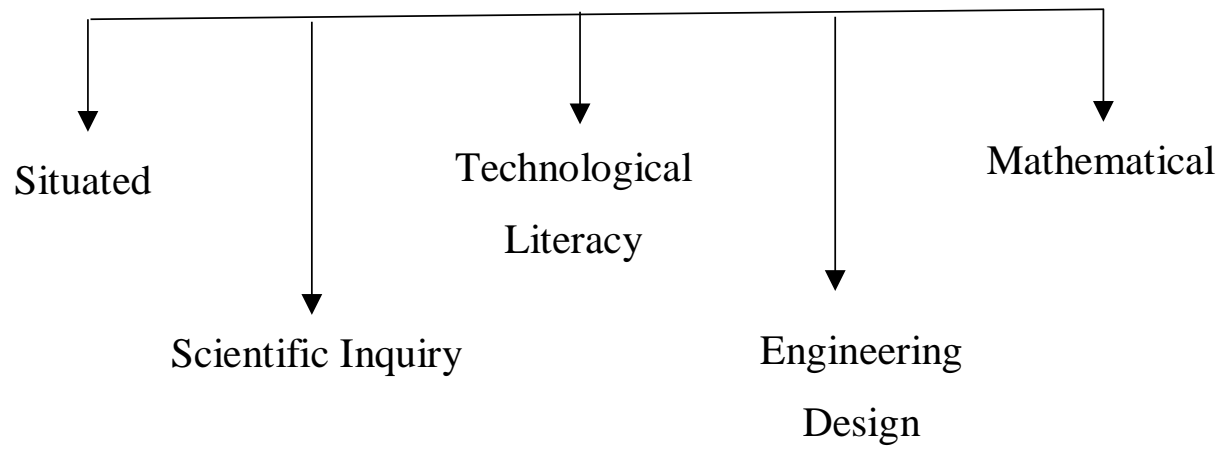

Figure 1. Theoretical Framework of the Study (Source: Kelley \& Knowles, 2016).

\section{Methodology}

This study adopted quantitative research design. According to Creswell (2013), a quantitative research is a type of research in which researcher observes the relationship among the different variables and measures the variables using statistical procedures for collection and analysis of data.

\subsection{Research Design}

In this study, survey design was used in order to achieve the objectives. Survey design was used because the purpose was to describe the opinions of the pre-service teachers regarding expected challenges in implementing STEM education and role of teacher education programs in mitigating these challenges and learn from them (Creswell, 2012).

\subsection{Sample}

Judgmental convenience sampling technique was used in this research. For this purpose, 202 pre-service teachers enrolled in three public universities of Quetta were selected to respond to the questionnaire. According to Fricker (2016), "convenience samples might also be useful for identifying issues, defining ranges of alternatives, or collecting other sorts of non-inferential data" (p. 20). The convenience sampling was used because random sampling and other types of probability sampling techniques could not be used due to winter vacations.

Data was collected from all (three) public-sector universities offering teacher education programs in Quetta. Data was collected between $15^{\text {th }}$ January 2020 to $20^{\text {th }}$ February 2020 when the universities were off due to winter vacations. Therefore, the researchers opted to use online survey. 
For this purpose, an online survey was designed in Google Forms and sent to the teacher educators of the respective universities and were requested to forward it to their pre-service teachers.

\subsection{Data Collection Tool}

For data collection a questionnaire was adapted from the study of Cinar et al. (2016) with permission. The questionnaire consisted of two parts: part 1 had questions related to expected challenges of implementing STEM education in Baluchistan while the part 2 had questions related to role of teacher education program in mitigating these challenges. The challenges were presented through 25 items while the role of teacher education programs in mitigating these challenges was measured by 19 items. The questionnaire was sent to one expert from SBK Women's University and one expert from University of Baluchistan in order to check its content validity. The scale was five points Likert Scale ranging from strongly disagree, disagree, neither agree nor disagree, agree, and strongly agree. The questionnaire was sent to the campuses of SBK Women's University for pilot study. After getting 14 responses the data was analyzed to check its Cronbach's alpha. The Cronbach's alpha value was .986 showing that the scale was highly reliable. In the start of questionnaire, the aim of the research was explained to make it clear to the respondent.

\subsection{Data analysis}

The data was analyzed using descriptive statistics using frequencies and percentage through SPSS 20 version.

\section{Findings}

The following tables present the findings of this study in line with the main objectives of the study.

Table 1: Expected challenges in implementing STEM education in Baluchistan

\begin{tabular}{llccc}
\hline S No. & \multicolumn{1}{c}{ Statements } & $\begin{array}{c}\text { Strongly } \\
\text { agree }\end{array}$ & Agree & Total \\
\hline 1 & Lack of sufficient material supply & $45.2 \%$ & $31.5 \%$ & $76.7 \%$ \\
2 & Unavailability of well-equipped laboratories & $45.7 \%$ & $24.9 \%$ & $70.6 \%$ \\
3 & Lack of systematic working & $47.2 \%$ & $32.5 \%$ & $79.7 \%$ \\
4 & Time management & $44.7 \%$ & $32.5 \%$ & $77.2 \%$
\end{tabular}


International Journal of Distance Education and E- Learning (IJDEEL) Volume V- Issue II (June, 2020)

\begin{tabular}{|c|c|c|c|c|}
\hline 5 & Unclear directions & $35.5 \%$ & $32.5 \%$ & $68 \%$ \\
\hline 6 & Lack of guidance & $37.1 \%$ & $38.6 \%$ & $75.7 \%$ \\
\hline 7 & The inclusion of multiple activities & $32.5 \%$ & $39.1 \%$ & $71.6 \%$ \\
\hline 8 & Lack of space for individual activities & $34.5 \%$ & $40.1 \%$ & $74.6 \%$ \\
\hline 9 & Lack of space for group activities & $36.0 \%$ & $38.6 \%$ & $74.6 \%$ \\
\hline 10 & Classroom strength & $29.9 \%$ & $44.2 \%$ & $74.1 \%$ \\
\hline 11 & Managing number of the groups & $26.9 \%$ & $49.2 \%$ & $76.1 \%$ \\
\hline 12 & Lack of teachers' expertise for integra & $29.9 \%$ subjects & $47.2 \%$ & \\
\hline
\end{tabular}

$77.1 \%$

13 Lack of teachers' expertise in using activities or $31.0 \% 43.1 \%$

experiments

$74.1 \%$

14 Lack of teachers' expertise in handling issues and $29.9 \% \quad 46.7 \%$

problem solving

$76.6 \%$

15 Issues in evaluation of students' progress $\quad 30.5 \% \quad 46.7 \% 77.2 \%$

16 Monitoring students free-time activities $31.5 \% \quad 38.5 \% \quad 70 \%$

17 Lack of collaboration among colleagues $\quad 33.5 \% 35.5 \% \quad 69 \%$

18 Lack of opportunities for in-service trainings $34.0 \% 39.6 \% 73.6 \%$

19 Lack of hands-on training for students $29.9 \% \quad 43.7 \% \quad 73.6 \%$

20 Poor facilities of instructional media $32.0 \% \quad 41.6 \% 73.6 \%$

22 Lack of investment and government interest in $35.5 \% \quad 39.6 \%$

STEM

$75.1 \%$

23 Lack of motivation of students towards these $34.5 \% \quad 41.6 \%$

subjects

$76.1 \%$

$24 \quad$ Lack of support from the school system $36.0 \% 41.6 \% 77.6 \%$

25 Poor planning for STEM education $\quad 36.0 \% \quad 41.6 \% 77.6 \%$

The table indicates that the biggest challenge that came out was 'lack of systematic working' which was 79.7\%. This was followed by 'poor planning' and 'lack of support from the school system' with $77.6 \%$. While 'Time management' and 'Issues in evaluation of students' progress' were the 
third most chosen challenges in implementing STEM education in Baluchistan in perception of pre-service teachers(77.2\%). One thing is clear from Table 1 that majority of the respondents have largely considered all practices as the expected challenges in implementing STEM education ranging from $79 \%$ to $70 \%$. However, only for two expected challenges the responses were below $70 \%$ as' Unclear directions' (68\%) and 'collaborative working with colleagues' (69\%).

Table 2: Role of teacher education programs in mitigating these challenges

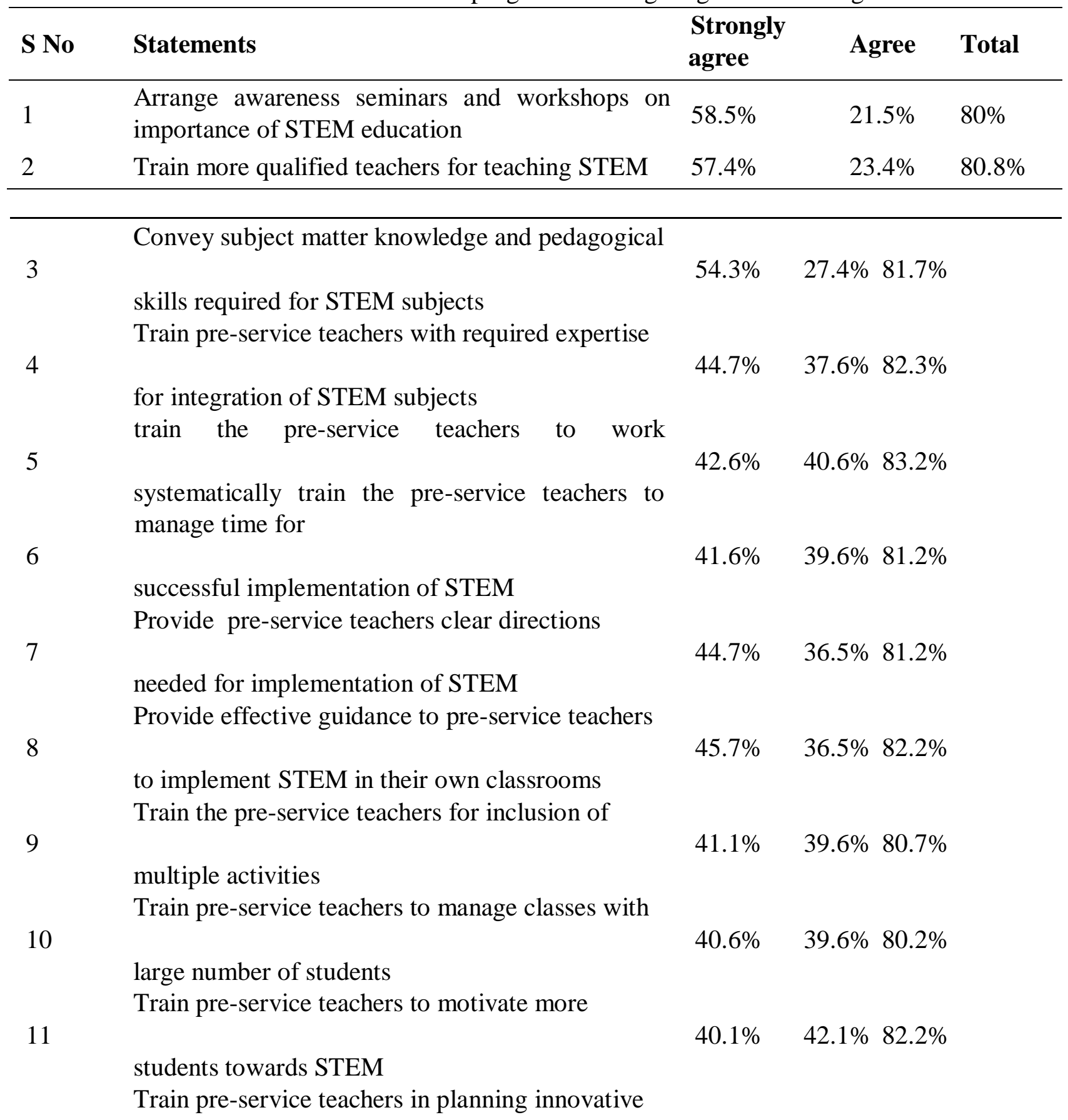


International Journal of Distance Education and E- Learning (IJDEEL) Volume V- Issue II (June, 2020)

12

subjects

Train pre-service teachers for using STEM related

13

activities or experiments

Train pre-service teachers in problem solving

14

strategies required for STEM

Train pre-service teachers in evaluating students'

15

16

progress in STEM

Train pre-service teachers for using different

activities

Train pre-service teachers to collaboratively work

$37.1 \% \quad 45.7 \% \quad 82.8 \% \quad$ with colleagues

Arrange trainings programs for in-service teachers

$44.2 \%$

$38.1 \% 82.3 \%$

Arrange trainings programs for students $\quad 45.2 \% \quad 35.5 \% \quad 80.7 \%$

Table 2 shows some interesting findings. Firstly, it is clear that pre-service teachers consider the role of teacher education programs very important in mitigating the challenges in implementing integrated STEM education in Baluchistan. As the total percentages for strongly agree and agree are $80 \%$ or above. Secondly, as table 1 shows that for successfully implementing STEM education, the biggest challenge is difficulty in systematic working, its solution for respondents is the teachers training programs. As it is the second highest percentage as $83.2 \%$ after 'Train pre-service teachers in problem solving strategies required for STEM' which is $84.3 \%$.

In addition to this, according to respondents the teacher education programs can train preservice teachers to work collaboratively with colleagues $(82.8 \%)$, for using different techniques for monitoring students free-time activities (80.7\%), in evaluating students' progress in STEM (82.2\%), for using STEM related activities or experiments $(82.2 \%)$, in planning innovative 
strategies for integrating and teaching STEM subjects (80.2\%), with required expertise for integration of STEM subjects (82.3\%), to manage time for successful implementation of STEM $(81.2 \%)$, for inclusion of multiple activities $(80.7 \%)$, to manage classes with large number of students $(80.2 \%)$, to motivate more students towards STEM (82.2\%), in planning innovative strategies for integrating and teaching STEM subjects (80.2\%). Moreover, according to respondents, the pre-service teacher education programs can provide pre-service teachers effective guidance $(82.2 \%)$ and clear directions $(81.2 \%)$ needed for implementation of STEM. According to respondents the pre-service teacher education institutions can arrange awareness seminars and workshops for in-service teachers (82.3), pre-service teachers (80) and for students (80.7) on importance of STEM education. Most importantly, they can convey subject matter knowledge and pedagogical skills required for STEM subjects $(81.7 \%)$.

\section{Discussion}

The results of this study showed that the implementation of integrated STEM education might face various challenges in Baluchistan. Firstly, a teaching force with all required knowledge and skills, able to design activities, experiments, and handling issues and challenges for integrating STEM education is required. For this purpose, the cream of dedicated and knowledgeable teachers should be attracted, deployed, and retained for teaching these subjects (National Science Board, 2007). Moreover, one of the challenges for successful implantation of STEM education is teachers' capabilities for teaching integrated STEM subjects and to be able to use more innovative teaching techniques involving multiple individual and group activities. Teachers' such pedagogical skills not only inculcate a deeper understanding of STEM but also apply such subjects in their future careers (Ejiwale, 2013; Meyrick, 2011).In the study of Dare et al. (2018) it was found that the teachers failed to properly integrate STEM subjects and more time was spend on science rather than on multiple disciplines. Moreover, the mastery of subject matter knowledge in all subjects is considered important for integrating STEM subjects (Dare et al., 2018).

The findings also revealed that successful implementation of STEM education requires some basic facilities such as classrooms feasible for STEM instructions via space and structure, well-equipped laboratories, audio and visual aids and especially technology related aids. According to Stohlmann et al. (2012), STEM requires space for activities and storage, infrastructure, and various materials and resources such as computers, tablets, multimedia, robotic 
kits, woods, glues and other instruments such screws, calculators, hammers. Such materials are necessary for implementing integrated STEM education successfully.

In addition to this, one of the major challenges in implementing STEM education is lack of well-motivated students towards STEM education and different activities to keep them motivated and engaged. Dare et al. (2018) found that although students get engaged in integrated STEM lessons however it is very difficult for teachers to keep this motivation and excitement for a long period of time. Moreover, Ejiwale (2013)and Meyrick (2011)strongly emphasized for promotion of more hands on and other related motivational activities for students in order to make them capable of using classroom knowledge and experiences into real world.

Findings also revealed that the challenges in implementing STEM education are time management and highly populated classrooms. These findings are in lined with Dare et al., (2018) who found that 'Our teachers felt the need to incorporate and balance the STEM disciplines, but struggled to find the 'time' to do this'( p.16). Moreover, Integrated STEM education cannot be taught without collaboration and teamwork. However, it was found that due to resource allocation and timetables such teamwork and collaboration could not be developed among teachers (Williams, 2011) .The schools and district education offices should provide ample support for teachers collaboration (Shernoff et al., 2017). In addition, the previous literature has shown that one of the barriers in STEM education is assessment of students activities (Pitt, 2018; Williams, 2011). These findings are also in agreement with Shernoff et al. (2017) who suggested that for assessing students success, adequate techniques are required to be developed' that evaluate students' application of concepts in addition to knowledge and comprehension' (p. 12).

Last but not least, the one of the biggest challenges in successful implementation of integrated STEM education is the lack of government interest towards STEM education. Firstly, implementation of STEM requires proper planning, clear directions, and proper guidance for all stakeholders. This stance has also been supported by Johnson (2012)who stated that for successful implementation of STEM a common and shared vision and strategic plans should be developed before implementation of STEM involving all stakeholders including parents. Johnson (2012) reported a case of a reform movement for implementing STEM education and found that one of the main reasons for the failure of that reform movement was due to poor planning where schools developed strategic and sustainability plans. 
For successful implementation of STEM government needs to invest on STEM education especially on teacher education and professional development programs (National Science Board, 2007). According to Honey et al. (2014), the effective implementation of STEM education requires appropriate investment, time and planning. In-service trainings and professional development opportunities are considered as playing key roles in effectively implementing STEM education (Meyrick, 2011).Most importantly clear directions and guidelines should be provided to teachers for planning integrated lessons and evaluating students success (National Science Board, 2007).

Although there are various challenges in implementation of integrated STEM education, teacher education institutions can play a vital role in training future teachers for implementing STEM education successfully. Pre-service teacher education programs make future teachers capable of using different strategies and techniques for minimizing the challenges and difficulties in implementing integrated STEM courses (Ryu et al., 2019). Such programs help in developing sound content knowledge and pedagogical skills (Ejiwale, 2013; Shernoff et al., 2017). The future teachers through such programs are trained to develop integrated lessons where one STEM discipline is integrated with others remarkably (Ryu et al., 2019).

Moreover, pre-service teacher education programs train future teacher not only innovatively design different activities and experiments but also design more interesting lessons for their students to raise their motivation and interest on STEM lessons. Pre-service teacher education programs develop future teachers capacities to effectively engage students in STEM learning and develop sense of teamwork and cooperation with the fellow teachers and STEM experts and researchers (Honey et al., 2014). These programs also help pre-service teachers to develop a sense of collaboration among colleagues (Ryu et al., 2019). Through getting STEM focused pre-service teacher education trainings the future teachers may enhance their students' spatial and psychomotor skills as well as their interest towards learning integrated STEM courses (Cinar et al., 2016). A sound teacher education program also makes future teachers able to engage students in STEM related projects and problem-based learning activities (Shernoff et al., 2017).

The pre-service teachers also go to schools for teaching practicum where they can get opportunities to learn from the experienced teachers involved in teaching integrated STEM courses. Such opportunities can guide pre-service teachers in teaching these subjects and managing their own classrooms (Shernoff et al., 2017). During the practicum sessions, the pre-service teachers receive all types of support needed for successful integration of STEM courses such as 
proper time, positive and timely feedback, and profound reflections (Koirala \& Bowman, 2003). Such support helps pre-service teachers in designing integrated innovative lessons and teaching strategies as well as developing more meaningful learning experience for their students (Ryu et al., 2019).

In addition to this, the teacher education programs offer different content courses and teaching courses. Such courses not only equip future teachers with content knowledge but also communicate the intended cognitive, effective and psychomotor outcomes of learning of the course, required teaching maxims and strategies, activities and other guidelines. An example of this is the teaching guides provided to B.Ed. (Hons.) elementary teachers to teach per-service teachers General Science and Mathematics content courses and Teaching of General Science and Mathematics professional courses in Pakistan. Such integrated STEM courses in pre-service teacher education programs provide appropriate national content guidelines teach integrated STEM subjects in classrooms as well as in laboratory (National Science Board, 2007).

\section{Conclusion}

This study indicated that although the implementation of integrated STEM education in Baluchistan may face acute challenges, the role of teacher education programs in mitigating these challenges is immense. Government of Baluchistan, Department Of Education, pre-service teacher education institutions and other stakeholders may design policies for implementing integrated STME education pre-service teacher education programs. The most talented students may be attracted towards integrated STEM pre-service teacher education programs with better pay scale and other incentives. The pre-service teacher maybe trained with integrated activity-based and inquiry-based learning models, so as teachers in their own classes they can use such models. More workshops and training are required at both pre-service and in-service level to demonstrate how STEM subjects are integrated via scientific inquiry.

One of the main limitations of this study is sampling technique as convenience sampling. Future research may use probability sampling techniques to enhance the validity, reliability and generalizability of the findings. In addition to this, this study was limited to pre-service teachers of public universities of Quetta. Future studies may collect data from the pre-service teachers of all elementary teacher education colleges and universities of Baluchistan. Moreover, the researchers may develop teaching models of integrated STEM and implement to see its effectiveness via 
experimental and quasi-experimental designs. Future studies may also investigate the prerequisite knowledge and skills of STEM teachers and need analysis of their professional development areas.

\section{References}

Asghar, A., Ellington, R., Rice, E., Johnson, F., \& Prime, G. M. (2012). Supporting STEM Education in Secondary Science Contexts. Interdisciplinary Journal of Problem-Based Learning, 6(2). https://doi.org/10.7771/1541-5015.1349

Awan, R.-N., Sarwar, M., Mehdi, M., Noureen, G., \& Anwar, N. (2017). Interests and Recruitment in Science: Factors Influencing Recruitment and Retention in STEM Education at University Level in Pakistan. Bulletin of Education and Research, 39(3), 19-43.

Breiner, J. M., Harkness, S. S., Johnson, C. C., \& Koehler, C. M. (2012). What Is STEM? A Discussion About Conceptions of STEM in Education and Partnerships. School Science and Mathematics, 112(1), 3-11. https://doi.org/10.1111/j.1949-8594.2011.00109.x

Cinar, S., Pirasa, N., \& Sadoglu, G. P. (2016). Views of Science and Mathematics Pre-service Teachers Regarding STEM. Universal Journal of Educational Research, 4(6), 1479-1487. https://doi.org/10.13189/ujer.2016.040628

Corlu, M., Capraro, R., \& Capraro, M. (2014). Introducing STEM Education: Implications for Educating Our Teachers For the Age of Innovation. Education and Science, 39(171), 74-85.

Dare, E. A., Ellis, J. A., \& Roehrig, G. H. (2018). Understanding science teachers' implementations of integrated STEM curricular units through a phenomenological multiple case study. International Journal of STEM Education, 5(1). https://doi.org/10.1186/s40594018-0101-z

Ejiwale, J. . (2013). Barriers to Successful Implementation of STEM Education. Journal of Education and Learning, 7(2), 63-74. https://doi.org/10.1007/978-3-319-24436-5_20

Gonzalez, H. B., \& Kuenzi, J. J. (2012). Science, technology, engineering, and mathematics (STEM): A Primer. In Congressional Research Service (Issue August). https://www.ccc.edu/departments/Documents/STEM_labor.pdf

Hmelo-Silver, C. E., Duncan, R. G., \& Chinn, C. A. (2007). Scaffolding and achievement in problem-based and inquiry learning: A response to Kirschner, Sweller, and Clark (2006). Educational Psychologist, 42(2), 99-107. https://doi.org/10.1080/00461520701263368

Honey, M. A., Pearson, G., \& Schweingruber, H. (2014). STEM integration in K-12 education: status, prospects, and an agenda for research. In STEM Integration in K-12 Education: Status, Prospects, and an Agenda for Research. https://doi.org/10.17226/18612

Johnson, C. C. (2012). Implementation of STEM Education Policy: Challenges, Progress, and Lessons Learned. School Science and Mathematics, 112(1), 45-55. https://doi.org/10.1111/j.1949-8594.2011.00110.x

Kelley, T. R., \& Knowles, J. G. (2016). A conceptual framework for integrated STEM education. International Journal of STEM Education, 3(1). https://doi.org/10.1186/s40594-016-0046-z 
Koirala, H. P., \& Bowman, J. K. (2003). Preparing Middle Level Preservice Teachers to Integrate Mathematics and Science: Problems and Possibilities. School Science and Mathematics, 103(3), 145-154. https://doi.org/10.1111/j.1949-8594.2003.tb18231.x

Kuenzi, J. J. (2008). Science, Technology, Engineering, and Mathematics ( STEM) Education : Background , Federal Policy, and Legislative Action. https://digitalcommons.unl.edu/crsdocs/35

Meyrick, K. M. (2011). How STEM education improves student learning. Meridian, 14(1), 1-5.

National Science Board. (2007). National action plan for addressing the critical needs of the U.S. science, technology, engineering and mathematics education system. https://www.nsf.gov/pubs/2007/nsb07114/nsb07114.pdf

Pitt, J. (2018). Blurring the Boundaries - STEM Education and Education for Sustainable Development. Design and Technology Education: An International Journal, 14(1), 37-48.

Ryu, M., Mentzer, N., \& Knobloch, N. (2019). Preservice teachers' experiences of STEM integration: challenges and implications for integrated STEM teacher preparation. International Journal of Technology and Design Education, 29(3), 493-512. https://doi.org/10.1007/s10798-018-9440-9

Shernoff, D. J., Sinha, S., Bressler, D. M., \& Ginsburg, L. (2017). Assessing teacher education and professional development needs for the implementation of integrated approaches to STEM education. International Journal of STEM Education, 4(1), 1-16. https://doi.org/10.1186/s40594-017-0068-1

Stohlmann, M., Moore, T., \& Roehrig, G. (2012). Considerations for Teaching Integrated STEM Education. Journal of Pre-College Engineering Education Research, 2(1), 28-34. https://doi.org/10.5703/1288284314653

Teo, T. W., \& Ke, K. J. (2014). Challenges in STEM Teaching: Implication for Preservice and Inservice Teacher Education Program. Theory into Practice, 53(1), 18-24. https://doi.org/10.1080/00405841.2014.862116

Williams, P. J. (2011). STEM Education: Proceed with caution. Design and Technology Education, 16(1), 26-35. 